\title{
PERILAKU KONSUMEN REMAJA DALAM MENGKONSUMSI MAKANAN CEPAT SAJI DI PIZZA HUT BASKO GRAND MALL
}

\author{
Maswati $^{1}$, Wirnelis Syarif ${ }^{2}$, Wiwik Gusnita ${ }^{2}$ \\ ${ }^{1}$ Alumni Program Studi Pendidikan Kesejahteraan Keluarga \\ ${ }^{2}$ Dosen Program Studi Pendidikan Kesejahteraan Keluarga \\ FPP Universitas Negeri Padang \\ Email: maswatimaswati2@gmail.com
}

\begin{abstract}
This study is based on the behavior of juvenile consumers in consuming fast food at Pizza Hut Basko Grand Mall. This study aims to determine consumer behavior in consuming fast food. The type of research used is descriptive research. The population is teenage consumers who come to Pizza Hut Basko Grand Mall restaurant is not known the exact number and taken samples through incidental sampling. Primary data in this study obtained directly from the respondents with the format of questionnaire. Analysis technique by determining the frequency distribution of data and determine the level of achievement of respondents. The results showed that the behavior of juvenile consumers in consuming fast food at Pizza Hut Basko Grand Mall is good. The behavior of juvenile consumers in consuming fast food at Pizza Hut Basko Grand Mall with sub indicators of good knowledge. The behavior of juvenile consumers in consuming fast food at Pizza Hut Basko Grand Mall with sub indicators of good attitude.
\end{abstract}

\section{Keywords: Consumer Behavior, Youth, Fast Food}

\section{PENDAHULUAN}

Pangan merupakan kebutuhan yang paling utama bagi penduduk. Di berbagai masyarakat, bahan makanan pokok memegang peranan utama dalam memenuhi kebutuhan penduduk, khususnya di Sumatera Barat masyarakat mengonsumsi nasi sebagai makanan pokok. Akan tetapi kebiasaan ini sudah berubah didukung oleh arus informasi yang sangat cepat, unsurunsur budaya lokal dapat dimasuki oleh budaya global dengan sangat cepat dan mudah. Salah satu unsur tersebut terkait dengan gaya hidup dan kebiasaan masyarakat dalam mengkonsumsi makanan.

Kegiatan masyarakat mengkonsumsi makanan dalam kehidupan sehari-hari sebagai pemenuhan kebutuhan ini membentuk kebiasaan konsumsi. Kebiasaan konsumsi adalah suatu pola perilaku konsumsi pangan yang diperoleh karena terjadi berulang- ulang.

Perilaku seseorang mencangkup dua hal yaitu pengetahuan, dan sikap. Dua hal tersebut merupakan bagian dari perilaku seseorang dalam mengkonsumsi makanan. 
Pengetahuan yang dimiliki seseorang akan menentukan makanan yang akan mereka konsumsi. Tingkat pengetahuan seseorang berbeda satu dengan lainnya. Hal tersebut akan menentukan sikap seseorang dalam menentukan makanan apa yang akan mereka konsumsi. Sikap seseorang yang memiliki pengetahuan yang baik tentang gizi makanan cenderung akan lebih berhati-hati dalam memilih makanan yang akan dikonsumsi.

Saat ini banyak masyarat yang mengkonsumsi makanan siap saji yang biasa kita kenal dengan istilah fast food. Makanan cepat saji (fast food) merupakan jenis makanan yang dikemas, mudah disajikan, praktis, atau diolah dengan cara sederhana. "Mudahnya memperoleh makanan siap saji di pasaran memang memudahkan tersedianya variasi pangan sesuai selera dan daya beli. Selain itu, pengolahan dan penyiapannya lebih mudah dan cepat, cocok bagi mereka yang selalu sibuk" Sulistijani, (dalam Ida 2016:31). Masyarakat dengan kesibukan dan kegiatan yang dilakukan setiap hari meyebabkan mereka tidak memiliki banyak waktu untuk memasak makanan sendiri. Hal tersebut menyebabkan masyarakat banyak yang beralih mengkonsumsi makanan cepat saji. Makanan cepat saji mempunyai kelebihan yaitu penyajian cepat sehingga hemat waktu dan dapat dihidangkan kapan dan dimana saja, tempat saji dan penyajian yang hygienis, dianggap makanan bergengsi, makanan modern, juga makanan gaul bagi anak muda.
Gaya hidup masyarakat yang sering mengkonsumsi makanan cepat saji (fast food) menjadi fenomena yang banyak terjadi, terutama masyarakat yang tinggal di kota-kota. Masalah ini juga menimpa sebagian masyarakat yang tinggal di kota Padang. Lokasi yang strategis, penyajian yang cepat, tempat yang nyaman, menu makanan dan minuman yang bermacam-macam, serta penyajian makanan yang berbeda dari restaurant cepat saji (fast food) membuat masyarakat tertarik memutuskan untuk membeli dan mengkonsumsi makanan cepat saji tersebut serta menjadikan restaurant sebagai salah satu tempat berkumpul favorit masyarakat kota Padang terutama kalangan remaja. Hal ini dapat kita lihat dengan banyaknya restaurant cepat saji yang terdapat di kota Padang dipenuhi oleh pengunjung yang sebagian besarnya adalah kalangan remaja.

Banyak remaja yang menjadikan restaurant cepat saji sebagi tempat berkumpul favorit mereka hanya karena mengikuti teman, menyesuaikan diri dengan teman dan juga karena peran dan status mereka dalam lingkungan bermain mereka. Berdasarkan penelitian awal yang penulis lakukan pada sejumlah konsumen remaja di Pizza Hut Basko, di ketahui bahwa sebagian besar konsumen mengkonsumsi Pizza Hut karena alasan Pizza Hut praktis dan mudah di dapat, kualitas produk yang terjamin, karena pengaruh lingkungan sosial seperti keluarga, teman dan lingkungan sosial. 
Keputusan remaja untuk mengkonsumsi makanan siap saji tersebut ditentukan oleh perilaku remaja sebagai konsumen. Perilaku konsumen merupakan faktor penting yang dapat mempengaruhi proses konsumen untuk membeli atau mengkonsumsi produk dan jasa. Hal ini sesuai dengan pendapat Multifiah:2002 (dalam Sangadji dan sopiah,2013:40), yang menjelaskan bahwa, "Perilaku konsumen akan menentukan proses pengambilan keputusan dalam pembelian mereka, proses tersebut merupakan sebuah pendekatan penyelesaian masalah pada kegiatan manusia untuk membeli suatu barang atau jasa dalam pemenuhan kebutuhan dan keiginannya".

Begitupun halnya dengan perilaku konsumsi makanan cepat saji oleh remaja, gaya hidup remaja yang terbiasa mengikuti tren menimbulkan keinginan yang besar dalam diri remaja untuk memutuskan mengkonsumsi makanan cepat saji yang banyak ditawarkan di restaurant, salah satunya adalah pizza hut.

Pizza Hut merupakan restaurant yang memberikan pelayanan secara full service mulai dari tamu akan masuk sampai dengan tamu keluar restaurant. Pizza Hut adalah salah satu restauran cepat saji yang menyajikan menu mulai dari hidangan pembuka, hidangan utama sampai hidangan penutup. Pizza merupakan makanan yang menjadi menu favorit. Selain pizza, juga ada menu utama lain seperti pasta dan nasi. Disamping banyaknya menu yang di tawarkan, Pizza Hut juga menyediakan menu paket dan promosi-promosi menu terbarunya. Menu paket merupakan menu yang banyak dipilih oleh kalangan remaja karena dengan harga yang murah mereka sudah bisa menikamati berbagai macam pilihan makanan dan minuman dengan porsi yang mengenyangkan.

Besarnya ketertarikan konsumen untuk menikmati makanan yang disajikan oleh Pizza Hut Basko, dapat dilihat dari data banyak pengunjung Pizza Hut Basko dari bulan Januari 2016 hingga Desember 2016 yang di hitung berdasarkan total bill dengan rata-rata tiap bulannya diperoleh bill sebanyak 3.000-an yang sebagian besarnya adalah remaja. Hal ini berarti kebiasaan remaja untuk menikmati makanan yang disajikan oleh Pizza Hut cukup tinggi dan tidak menurun, para remaja memutuskan untuk memilih Pizza Hut sebagai salah satu tempat favorit mereka untuk menikmati makanan siap saji (fast food). Untuk itu remaja perlu mempunyai bekal pengetahuan makanan yang baik agak sikap konsumsi remaja menjadi lebih baik.

\section{METODE PENELITIAN}

Penelitian ini termasuk pada jenis penelitian deskriptif. Penelitian ini dilakukan di restaurant Pizza Hut Basko Grand Mall Padang. Populasi penelitian ini adalah konsumen remaja yang datang ke restaurant Pizza Hut Basko Grand Mall padang yang tidak diketahui jumlahnya secara pasti. Sampel dalam penelitian ini adalah konsumen remaja yang telah menikmati menu di Pizza 
Hut Basko Grand Mall pada 21 Agustus- 21 September 2017. Data yang diperlukan dalam penelitian ini adalah data primer yang merupakan data langsung dari sampel penelitian berupa angket mengenai perilaku konsumen remaja dalam mengkonsumsi makanan cepat di Pizza Hut Basko Grand Mall Padang. Data yang diperoleh dalam penelitian ini dikumpulkan dari sumber data dengan teknik pengumpulannya menggunakan angket.

Langkah-langkah dalam pengolahan data penelitian ini yaitu mentabulasikan data, menghitung frekuensi masing-masing dari jawaban yang diberikan responden. Mengklasifikasi skor kedalam kategori untuk melihat tingkat pencapaian responden. Dan menghitung hasil persentase dari setiap indikator.

\section{HASIL DAN PEMBAHASAN \\ Indikator Pengetahuan}

Setelah diperoleh hasil perhitungan statistik untuk indikator pengetahua dapat dilihat pada Tabel 1 .

Tabel 1. Distribusi

Frekuensi

Pengetahuan

Konsumen

Remaja Dalam Mengkonsumsi Makanan Cepat saji di Pizza Hut Basko Grand Mall

\begin{tabular}{|c|c|c|}
\hline Pengetahuan & F & \% \\
\hline Sangat Baik & 45 & 45 \\
\hline Baik & 43 & 43 \\
\hline Cukup Baik & 12 & 12 \\
\hline Total & 100 & 100 \\
\hline
\end{tabular}

Berdasarkan Tabel 1 diatas dapat dilihat bahwa perilaku konsumen remaja dalam mengkonsumsi makanan cepat saji di tinjau dari indikator pengetahuan sebanyak 45 orang $(45 \%)$ responden menyatakan sangat baik, 43 orang $(43 \%)$ responden menyatakan baik dan 12 orang (12\%) responden menyatakan cukup baik. Hal ini berarti perilaku konsumen remaja dalam mengkonsumsi makanan cepat saji ditinjau dari indikator pengetahuan berada dalam kategori Baik. Sesuai dengan pendapat Ika (2012:97) bahwa:

"Pengetahuan merupakan salah satu pertimbangan seseorang dalam memilih dan mengkonsumsi makanan. Semakin baik pengetahuan gizi seseorang maka akan semakin memperhatikan kualitas dan kuantitas pangan yang di konsumsinya. Orang yang semakin baik pengetahuan gizinya akan lebih banyak mempergunakan pertimbangan rasional dan pengetahuannya dibandingkan panca indera sebelum mengkonsumsi makanan".

Bagi para remaja makanan akan berpengaruh pada perkembangan kecerdasan dan sebagainya karena itu hal pengetahuan gizi betul-betul harus memperoleh perhatian dari setiap remaja, tidak hanya pemahaman mengenai jenis-jenis pangan dan gunanya bagi badan melainkan juga mengenai cara-cara memperoleh serta mengolah dan mempertimbangkan agar manusia tetap sehat.

Dalam hal ini pengetahuan merupakan salah satu faktor internal yang mempengaruhi perilaku seseorang, perilaku yang ditunjukkan akibat pengaruh pengetahuan akan berbedabeda karena dipengaruhi pula oleh 
faktor eksternal yaitu pengaruh lingkungan, sehingga perilaku yang tampak pada seseorang berbeda-beda tergantung dari faktor yang dominan dari kedua faktor tersebut. Adanya kecenderungan pengetahuan yang baik pada responden penelitian ini kemungkinan disebabkan karena lingkungan responden mendukung untuk memiliki pengetahuan yang baik pula, sehingga pemilihan makanan cepat saji yang baik dari lingkungan mendorong mereka juga untuk terbiasa memilih makanan cepat saji yang baik.

Responden dalam penilitian ini secara keseluruhan memiliki pengetahuan yang baik. oleh karena itu, akan lebih baik jika memang pengetahuan baik yang dimiliki tersebut dipertahankan agar menjadi suatu perilaku yang baik dalam memilih ataupun mengkonsumsi makanan cepat saji.

Tabel 2 . Distribusi Frekuensi Pengetahuan Konsumen Remaja Dalam Mengkonsumsi Makanan Cepat saji di Pizza Hut Basko Grand Mall

\begin{tabular}{|c|c|c|}
\hline Pengetahuan & f & \% \\
\hline Sangat Baik & 10 & 10 \\
\hline Baik & 74 & 74 \\
\hline Cukup Baik & 16 & 16 \\
\hline Total & 100 & 100 \\
\hline
\end{tabular}

Dari tabel diatas diketahui bahwa konsumen memiliki sikap baik dalam mengkonsumsi makanan cepat saji di Pizza Hut Basko Grand Mall karena persepsi mereka terhadap produk dan layanan yang mereka terima. Hal ini dapat dilihat dari hasil respon yang sangat baik oleh responden yaitu pada pernyataan bahwa mereka mengkonsumsi pizza hut yang merupakan salah satu makanan cepat saji karena tampilan produk yang menarik, praktis dan mudah didapat, hygenis, serta memiliki tempat yang nyaman dan pelayanan yang diberikan juga ramah. Sesuai dengan pendapat Ika (2012:97), "Perilaku sesorang didasari oleh sikap dan norma subjektif. Maksudnya jika seseorang mempersepsikan bahwa hasil dari menampilkan suatu perilaku tersebut positif, ia akan memiliki sikap positif terhadap perilaku tersebut serta kebalikannya".

Soekidjo dalam Ida (2016:20)juga memaparkan, sikap merupakan reaksi atau respon yang masih tertutup dari seseorang terhadap stimulus atau objek. Sikap dalam hal ini dapat dipandang sebagai suatu tingkatan afeksi baik yang bersifat positif maupun negatif dalam hubungannya dengan objek-objek psikologis.Afeksi yang positif yaitu afeksi senang, sedangkan afeksi yang negatif adalah afeksi yang tidak menyenangkan.

Jadi dapat disimpulkan bahwa responden dalam penilitian ini secara keseluruhan memiliki sikap yang baik dalam perilaku komsumsi makanan cepat saji di Pizza Hut Basko Grand Mall. Namun sikap baik ini perlu dipertahankan bahkan ditingkatkan agar menjadi suatu perilaku yang baik dalam memilih ataupun mengkonsumsi makanan cepat saji. 


\section{KESIMPULAN DAN SARAN}

\section{Kesimpulan}

Berdasarkan hasil penelitian dan pembahasan, kesimpulan yang dapat di ambil dari perilaku konsumen dalam mengkonsumsi makanan cepat saji di Pizza Hut Basko Grand Mall adalah sebagai berikut:

a. Perilaku konsumen remaja dalam mengkonsumsi makanan cepat saji di Pizza Hut Basko Grand Mall secara keseluruhan dinilai baik yang mana 25 orang $(25 \%)$ responden sangat baik, 65 orang (65\%) responden baik dan 10 orang (10\%) responden cukup baik.

b. Pada indikator pengetahuan diketahui bahwa responden yang ikut dalam penelitian ini banyak memiliki pengetahuan yang baik dalam mengkonsumsi makanan cepat saji di Pizza Hut Basko Grand Mall. Rata-rata tingkat capaian responden untuk indikator pengetahuan ini adalah 1,50 dengan TCR $75,17 \%$ yang berada pada kategori baik. Hal ini berarti remaja mengetahui dengan baik kualitas makanan yang mereka konsumsi, baik atau tidak utuk kesehatan tubuh mereka.

c. Dalam indikator sikap diketahui bahwa responden juga memliki sikap yang baik dalam mengkonsumsi makanan cepat saji di Pizza Hut Basko Grand Mall. Rata-rata tingkat capaian responden untuk indikator sikap ini adalah 1,47 dengan TCR $73,48 \%$ yang berada pada kategori baik. Hal ini berarti sikap remaja dalam mengkonsumsi makanan sudah baik.

\section{Saran}

\section{Bagi Konsumen}

Perilaku konsumen remaja yang baik dalam mengkonsumsi makanan cepat saji di Pizza Hut Basko Grand Mall Padang sebaiknya dapat di pertahankan dan tetap memperhatikan kandungan gizi yang terdapat pada makanan agar tidak membahayakan kesehatan.

\section{Peneliti Selanjutnya}

Kepada peneliti selanjutnya disarankan agar dapat melanjutkan penelitian ini dengan menambah variabel-variabel baru dan menggunakan analisis yang lebih mendalam lagi.

\section{DAFTAR PUSTAKA}

Fakultas Pariwisata Dan Perhotelan. 2016. Buku Paduan Penulisan Tugas Akhir Fakulatas Pariwisata Dan Perhotelan. Padang: Universitas Negeri Padang

Ida Cholidatul Janah. 2016. "Kebiasaan Konsumsi Makanan Cepat Saji Pada Siswa Kelas VIII SMP Negeri 1 Yogyakarta". Skripsi. Yogyakarta: Universitas Negeri Yogyakarta.

Ika Suswanti. 2013. "FaktorFaktor Yang Berhubungan Dengan Pemilihan Makanan Cepat Saji Pada 
Mahasiswa Kedokteran Dan

Ilmu Kesehatan UIN Syarif

Hidayatullah Jakarta".

Skripsi. Jakarta: Universitas

Islam Negeri Syarif

Hidayatullah

Sangadji dan Sopiah. 2013.

Perilaku

Konsumen.

Yogyakarta: Andi 